\title{
Das Máscaras Africanas Ao Romance Brasileiro Do Século XX - trajetórias, usos e sentidos do negrismo
}

Luiz Henrique Silva de Oliveira ${ }^{1}$

\section{RESUMO}

Este trabalho pretende conceituar o negrismo enquanto procedimento literário do século XX e estudar suas manifestações e trajetórias até chegar ao romance brasileiro do referido período. Será necessário para isso evidenciar suas fontes e influências, estabelecer diálogo com outros sentidos que o termo possui. Finalmente, deseja-se evidenciar como a linhagem negrista no romance brasileiro do período em questão representou uma etapa de transição entre a literatura de perspectiva etnocêntrica, em relação ao negro, e a chamada literatura afro-brasileira.

Palavras-chave: negrismo; romance; Literatura Brasileira.

\section{ABSTRACT}

This work aims to conceptualize negrismo as a twentieth century literary procedure, and to study its manifestations in Brazilian novels. Therefore, in order to establish a dialogue with other meanings implied in the term, it is necessary to investigate its origins and its influences. Finally, it is our purpose to demonstrate how the "negristas" Brazilian novel written in the period in question represents a stage of transition between the literature of ethnocentric perspective in relation to the black subject, and African-Brazilian Literature as such.

Keywords: negrismo; novel; Brazilian literature.

\section{Palavras iniciais}

Não é exagerado afirmar que desde o início da formação de nossa literatura até o terceiro quartel do século XX, a produção de autoria negra não conseguiu se desenvolver enquanto tradição romanesca. Seja pela dificuldade de escritores negros acessarem o mercado editorial, seja devido ao pernicioso processo de exclusão dos meios simbólicos de poder, operado após a abolição, o fato é que, no referido período, majoritariamente foram os autores brancos que cumpriram a função de escrever, "de fora para dentro", os afrodescendentes, em suas mais variadas formas, até a consolidação de um sistema literário que os representasse "de dentro para fora". Defendo que este sistema romanesco de corte afro-brasileiro somente foi possível existir a partir da afirmação literária da geração Cadernos Negros, ou seja, a partir de 1978. Antes deste momento penso que seja mais apropriado falar em esparsas manifestações literárias afro-brasileiras, ao menos do ponto de vista do romance.

1 Luiz Henrique Silva de Oliveira é doutor em Teoria da Literatura e Literatura Comparada pela UFMG (2013), onde também concluiu mestrado (2007) em Teoria da Literatura e Graduação em Letras - Língua Portuguesa (2004). Integra o Núcleo de Estudos Interdisciplinares da Alteridade (NEIA-UFMG) e o grupo de pesquisa Literatécnica (CEFET-MG). Atualmente, é Professor do Centro Federal Tecnológico de Minas Gerais - CEFET-MG. Autor do livro Poéticas negras (2010). Email: henriqueletras@yahoo.com.br 
Não quero com isso dizer que não houve em nossa história literária romances escritos por afrodescendentes. De acordo com Eduardo de Assis Duarte (2007) e Florentina Silva Souza, Úrsula (1859), de Maria Firmina dos Reis, é o primeiro romance de autoria afro-brasileira. Reconheço que, ao longo de nossa história literária, ocorreram outras produções romanescas com autoria, temática, ponto de vista, linguagem e temas negros. São exemplos: fragmentos de Machado de Assis (Duarte, 2007); Vencidos e degenerados (1915), de Nascimento Moraes; Água Funda (1945), de Ruth Guimarães; Clara dos anjos (1948), de Lima Barreto; A maldição de Canaã (1951), de Romeu Crusoé; Negra Ifigênia, paixão do senhor branco (1961), de Anajá Caetano; Ifigênia está no fim do corredor (1969), de Nataniel Dantas; O bicho que chegou à feira (1991) e Bola da vez (1994), de Muniz Sodré; O justiceiro (1992), de Ramatis Jacino; Breves estórias de Vera Cruz das Almas (1991), Estórias da mitologia - o cotidiano dos deuses (1995), Capitu: memórias póstumas (1998), de Domício Proença Filho; Crônica de indomáveis delírios (1991), de Joel Rufino dos Santos; Cidade de Deus (1997), de Paulo Lins; Ópera negra (1998), Joana e Joanes (1999), de Martinho da Vila $^{2}$.

Esse painel demonstra que, tendo em vista o desenvolvimento teórico proposto por Antonio Candido (1959), ainda não se pode assegurar a existência de um sistema romanesco afrobrasileiro, se é que é possível esse delineamento. Isso porque, de acordo com Candido, sistema define-se pela articulação de autores, obras e público de maneira a estabelecer uma tradição. Esta gera continuidade, que dá à produção literária o caráter de atividade permanente, associada aos outros aspectos e manifestações da cultura. E é exatamente a continuidade que faltou durante bom tempo à literatura produzida por afrodescendentes, ao menos se considerarmos o romance durante $\mathrm{o}$ século XX. E, além disso, não houve, durante séculos, a permanência desta articulação que caracteriza o sistema, embora a partir das duas últimas décadas do século passado este cenário esteja se alterando.

A visão de Candido diverge da historiografia literária tradicional, porque adota como critério classificatório a constituição da literatura como atividade regular na sociedade, não a literatura unicamente como expressão de algum sentimento nacional. Percebo, no âmbito dos meus

2 Nosso recorte temporal para este trabalho é o século XX. Porém, vale destacar os seguintes romances escritos por afro-brasileiros no início do século XXI: Eu, Zeus (2000), Nós, as deusas do Olimpo (2000) e Os deuses, menos o pai (2000), de Domício Proença Filho; Paulo e Virgínia (2001), Bichos da terra tão pequenos (2010) e Claros sussurros de celestes ventos (2012), de Joel Rufino dos Santos; Memórias Póstumas de Teresa de Jesus (2003), Os Lusófonos (2006), Vermelho 17 (2007), A serra do rola-moça (2009) e A rainha de bateria (2009), de Martinho da Vila; Desde que o samba é samba (2012), de Paulo Lins; Ponciá Vicêncio (2003) e Becos da memória (2006), de Conceição Evaristo; Um defeito de cor (2006), de Ana Maria Gonçalves; Graduado em marginalidade (2005) e Estação terminal (2010), de Sacolinha (Ademiro Alves). 
levantamentos, que há uma inconstância de produções romanescas de autoria negra no século XX, o que contraria a continuidade da cadeia gerada entre autores e consumidores de literatura, segundo Candido.

A quem coube, portanto, escrever os negros, já que eles sempre estiveram presentes enquanto tema em nossa literatura? Seria possível falar em uma formulação brasileira de negrismo? Como se definiria este negrismo? Como chegamos até aqui?

\section{Percursos do negrismo}

Segundo a fortuna crítica disponível, no Brasil, o termo negrismo foi primeiramente utilizado por Lima Barreto, mesmo não tendo ele detalhado o que entendia por tal termo. Em seu Diário íntimo, publicado somente em 1956, o autor apenas confessa o desejo de escrever um "Germinal negro" e "fundar o negrismo na literatura brasileira" (Barreto, 1956, p.84). Não se trata de afirmar que o autor esteja ligado ao negrismo de que este trabalho se ocupa, mas sim de pontuar que a palavra é utilizada em sentido distinto do que aqui se adota. No diário, Barreto não deixa claro o significado da palavra e o "Germinal" a que ele se refere aponta para a escrita da trajetória dos negros oprimidos através da literatura.

O primeiro mapeamento sobre o negrismo realizado por um brasileiro foi o de Jorge Schwartz (1995), referindo-se primeiramente a uma linhagem poética caribenha da primeira metade do século XX. Na visão do crítico, esta linhagem estava preocupada, sobretudo, com a valorização da identidade cultural afrodescendente. Propunha rediscutir a formação multicultural, a natureza do processo histórico, as relações entre dominantes e dominados naquele espaço. Cultivou a poesia social e a lírica tradicional, ou seja, associou o ritmo tradicional desta ao caráter empenhado daquela, o que resultou num profundo conteúdo humano e em uma excepcional musicalidade, "retirados" do povo e dirigidos ao povo.

Ainda segundo Schwartz, além do negrismo na lírica antilhana, o negrismo também se manifestou na poesia brasileira. Para o crítico, o negrismo, enquanto manifestação estritamente literária, pouquíssimo dialoga com a negritude, entendida como os movimentos surgidos nos anos de 1930, em Paris, que reivindicaram direitos dos negros, em diversas ordens. A literatura aqui é 
"ponta de lança" para externar demandas sociais, políticas e existenciais do coletivo negro de maneira geral. Vale destacar que o negrismo não se configura como um movimento estético organizado, regido por manifestos ou por propostas teóricas, análogo aos ismos do início do século $\mathrm{XX}$. Nem por isso, entretanto, deixam de existir pontos de contato entre o negrismo e certos procedimentos característicos das vanguardas europeias. A busca do exotismo, a introdução de uma camada estética baseada na plástica dos fetiches africanos ou das máscaras tradicionais e o retorno aos elementos "primitivos" da cultura aproxima, no mínimo, o negrismo do Cubismo.

Tal como entendido por Jorge Schwartz, o negrismo admite uma linhagem de autores que (re) produziram um vasto "repertório importado", um discurso plástico, na maioria das vezes enunciada por uma elite branca e que incorporou temáticas relativas ao universo negro, a fim de divulgá-las junto a um público também branco e da própria elite.

Ainda de acordo com Schwartz, estes autores estiveram preocupados com a exploração de elementos culturais africanos ou trazidos na diáspora e vistos como exóticos, a divulgação da culinária, da musicalidade e da dança de origem africana, ou seja, com um "folclorismo negro" que anima boa parte de suas produções artísticas em verso e atualiza o sentido nacionalista e coletivista dos primeiros anos do Modernismo brasileiro. O estudioso, contudo, desconsidera o romance, talvez não percebendo que este gênero tenha sido bastante frutífero do ponto de vista do negrismo.

O sentimento de valorização do coletivo negro aflora desde o final do século XIX e primeiros anos do século XX, o que antecede inclusive o estabelecimento do termo "negritude" em nossa língua. Vale ressaltar que, mesmo com o advento da imprensa negra, o romance de corte afrobrasileiro não se desenvolvia sistematicamente, tampouco as pontuais manifestações romanescas ganhavam espaço em robustos estudos da primeira metade do século XX. Assim, parece que minha hipótese se confirma: autores brancos, a partir de suportes formais ocidentais, por dentro e por fora do cânone, a partir de um ponto de vista simpático, mas externo, relatam temas e situações relativos ao coletivo afrodescendente.

Na esteira destas reflexões, defendo que não é a partir dos anos de 1960, conforme admite Jorge Schwartz, em "Negrismo e negritude", nem mesmo a partir dos anos de 1930, de acordo com David Brookshaw (1983), mas sim a partir de 1928, com Mário de Andrade, que os autores aqui chamados de negristas, devido aos seus procedimentos composicionais, buscavam desempenhar uma representação positiva do afrodescendente, ora destacando seus feitos e participações heroicas 
em nossa história, ora satirizando os "donos-do-poder", ora colocando em evidência tanto os heróis históricos quanto aqueles anônimos do dia a dia, ora remontando o contexto de trocas diversas na diáspora.

O que chamo de negrismo no universo do romance brasileiro, segundo resultados de meu levantamento, estende-se de 1928, com Macunaíma, de Mário de Andrade, até 1999, com O trono da rainha Jinga, de Alberto Mussa. Destaco ainda: O mameluco Boaventura (1929), de Eduardo Frieiro; Jubiabá (1935), O compadre Ogum (1964) e Tenda dos milagres (1969), de Jorge Amado; A marcha (1941), de Afonso Schmidt; Xica da Silva (1976), Ganga Zumba (1962) e Benedita Torreão da Sangria Desatada (1983), de João Felício dos Santos; Chica que manda (1966), Gongo sôco (1966) e Suor e sangue (1948), de Agripa Vasconcelos; O forte (1965), Luanda beira Bahia (1971), de Adonias Filho; A casa da água (1969), O rei de Keto (1980) e Sangue na floresta (1981), de Antonio Olinto; Os tambores de São Luís (1975), de Josué Montello; Viva o povo brasileiro (1984), de João Ubaldo Ribeiro; Rei branco, rainha negra (1991), de Paulo Amador. Este panorama não significa que proponho um levantamento acabado e imutável.

O negrismo, portanto, não é um movimento literário articulado através de manifestos ou documentos. Trata-se de um conjunto de procedimentos adotados por diversos artistas em suas respectivas linguagens. Como fenômeno, compõe-se por uma linhagem de autores, segmentada, por sua vez, em tendências específicas. Inicia-se no princípio do século XX, na Europa, no momento em que os artistas de vanguarda procuram em África motivos para a renovação estética que acontecia naquele momento. A recuperação de signos no continente-mãe ocorre em outros territórios, como no Caribe, na América Latina e no Brasil.

\section{Ponto de partida: as máscaras africanas}

Diversos artistas europeus do início do século XX beberam em boa parte da produção africana e esta se incorporou ao nosso universo e o enriqueceu extraordinariamente. Resguardando limites e proporções, alterou-se a forma ocidental de olhar para as esculturas que se veneravam e se veneram nas aldeias africanas. Agora, não são tidas como mal-acabadas disformes e grotescas. Aprendeu-se a reconhecer nelas a inventiva criadora e o rigor na escolha das formas para impregná- 
las de forma e beleza. Ainda segundo Costa e Silva, dois tipos de máscaras foram às fontes em que beberam as vanguardas artísticas europeias, sobretudo o Cubismo: Dan e Geledé.

Tomemos esta como exemplo. Costa e Silva (2009) explica que os Dans, da Costa do Marfim e da Libéria fazem, por exemplo, um tipo de "máscara coberta de um negro brilhante" na qual o rosto se simplifica numa testa abaulada, "num nariz fino e ligeiramente arrebitado, num queixo em ponta, numa boca projetada e entreaberta, como num muxoxo" (Costa e Silva, 2009, p. 27) e em dois buracos grandes e redondos no lugar dos olhos. Essa máscara, a que chamam gungye ge e zapkei ge, pode estar emoldurada por um trançado de fibras, no qual algumas vezes se acrescenta o cauri (concha).

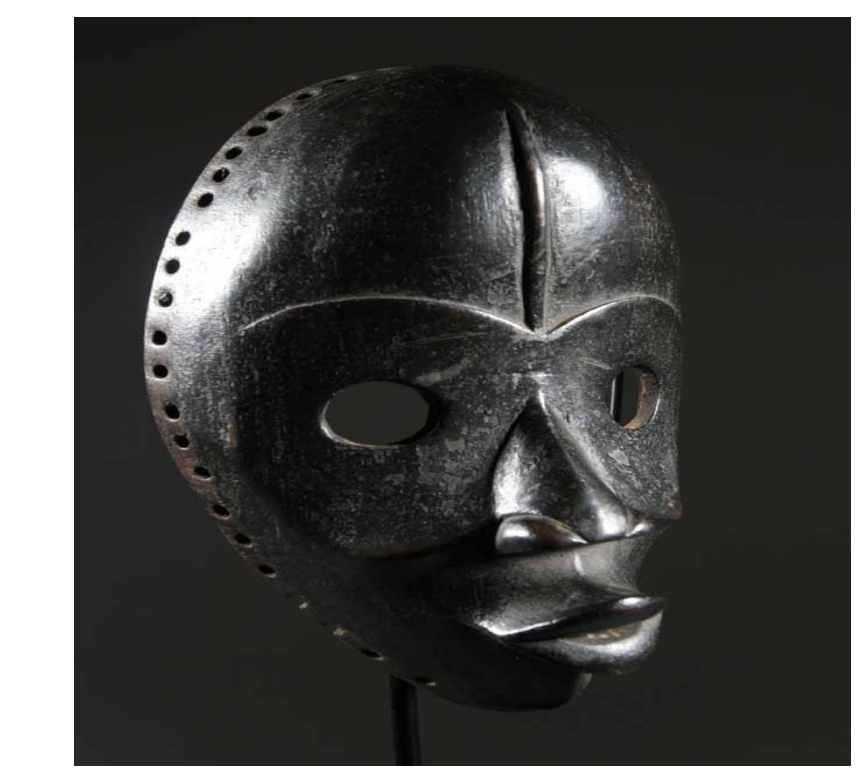

Máscara Dan. Libéria Dan. Século XIX. Madeira e ferro. Altura $26 \mathrm{~cm}$. Coleção Etta Donner adquirida em 1940. http://www.masque-africain.com/masques-africains.html, Acesso em 13 de março de 2012.

O diplomata ainda ensina que os mesmos Dans esculpem, contudo, outra máscara, toda ao contrário daquela apresentada anteriormente: de corte rude na madeira, veem-se os golpes da enxó e a face humana é alongada, sem queixo, numa enorme boca aberta, que se conjuga com a testa e as sobrancelhas também projetadas, em bloco, para frente; o nariz é pequeno, mas a seu lado dois cilindros grossos, ocos e salientes dizem que são os olhos (Costa e Silva, 2009, p.27).

Finalmente, é válido sublinhar que as máscaras focalizam o rosto. Logo, evidenciam traços fenotípicos marcantes da diferença em relação aos modelos ocidentais, como o nariz, os lábios, a testa e o cabelo. Estes signos corporais chamam a atenção do espectador e ajudam a configurar o 
exotismo da arte africana, quando lida pelas lentes eurocêntricas. São signos, pois, que afirmam a especificidade africana justamente porque são opostos ao rosto, entendido como configuração identitária, e à estética ocidentalizada.

Antes mesmo da Primeira Guerra Mundial, a influência africana já se fazia presente na poesia, na música e nas artes plásticas europeias. Movidos por um desejo de inserir nas artes uma nova sensibilidade e novas emoções, vários artistas europeus beberam nas fontes da então chamada "arte negra". Em seguida, a "contaminação" da arte negra chegou até as Antilhas e América Latina, justamente por causa da influência intelectual bastante forte exercida pela Europa nestes espaços. Este cenário, portanto, configura a gênese do negrismo como procedimento literário.

\section{Primeira parada: apropriações cubistas}

Les Demoiselles d'Avignon, obra de Pablo Picasso, construída durante o ano de 1907, sem dúvida alguma foi o elemento deflagrador do cubismo. Além disso, tanto o tema tratado, com conotações eróticas, quanto à técnica, se desenvolveram essencialmente como uma espécie de arte preocupada com uma reavaliação e reinvenção de procedimentos e valores pictóricos bastante díspares daqueles pregados pela art nouveau e pela lógica ocidental. John Golding, por exemplo, assegura que, apesar desta rejeição de muitos dos aspectos representados por Les Demoiselles, é inegável a contribuição do quadro para o avanço do movimento emergente, uma vez que colocou os problemas pictóricos que os cubistas viriam a solucionar (Golding, 1959, p. 51). 


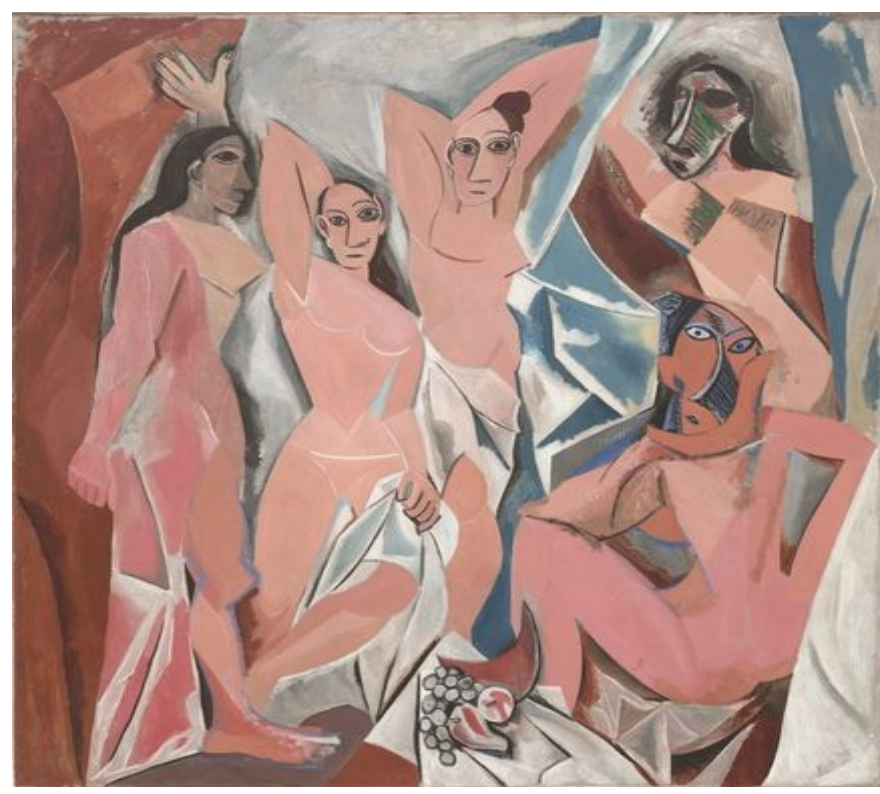

Les Demoiselles d'Avignon (1907).

http:// www.moma.org, acesso em 17 de abril de 2011.

Presentes já na feição das personagens representadas no quadro em questão, as máscaras africanas, uma das mais complexas formas de escultura daquele continente, inspiraram Picasso a retratar o corpo (e o rosto) humano de forma mais conceitual, isto é, a partir da valorização de detalhes, como a redução da anatomia a triângulos e losangos geométricos, bem como o abandono das proporções anatômicas, tal como ocorria nas máscaras dans e geledés. A influência africana é ainda mais evidente nas faces tipo "máscara" das duas personagens que estão no lado direito do quadro. Dar-se-ia início ao que Picasso denominou "l'époque nègre” (Braque et alli, 1997, p. 7).

Cubistas do porte de Paul Guillaume, por exemplo, admitem a arte africana como fonte e influência do movimento, chegando a tecer elogios que apontam também para uma dívida pouco reconhecida pelo mundo branco com relação às contribuições do mundo negro no campo estético:

On peut dire sans crâinte d'exagération que la meilleure partie de ce qu'a produit l'art contemporain pendant des vingt dernières anées doit son inspiration originale à la sculpture primitive nègre. Cela est, bien entendu, particulierement évident en ce que qui concerne les arts plastiques, non seulemetnt dans la sculpture de Lipchitz et d'autres chefs, mais également dans le domaine de la peinture, où Picasso, Matisse, Modigliane et Soutine reconnu comme des influences determinantes parmi les jeunes - ont adopté le motif nègre avec des modifications créatrices (Guillaume, 2006, p.7-8) . $^{3}$.

3 "Pode-se dizer sem medo de exagerar que a melhor parte do que produziu a arte contemporânea durante os últimos vinte anos deve sua inspiração original à escultura primitiva negra. É, entenda-se bem, particularmente evidente que o que concerne às artes plásticas, não somente com relação à escultura de Lipchitz e de outros artistas, concerne igualmente ao domínio da pintura, no qual Picasso, Matisse, Modigliane e Soutine - reconhecidos como influência 
Para além da contabilidade de influências, incidente em novas gerações de artistas da Europa e Américas, Apollinaire nos permite vislumbrar que os cubistas não só se apropriaram dos motivos, materiais e formas "primitivas" africanas, mas os recriaram, a fim de atingir o gosto europeu pelo exótico e/ou chocar o público, como era prática no início do século XX. Assegurando limites e proporções, pode-se dizer que, do suporte duro da madeira, o conjunto de influências africanas migra para as telas dos pintores e, num momento posterior, para as páginas da literatura. Neste processo, há inevitáveis adaptações, apropriações, releituras e (des) leituras, de modo à reconfigurar relações e conceitos entre o imaginário europeu e o continente africano, como o próprio Braque admite: “[les masques africaines] m'ont ouvert un horizont nouveau. Ils m'ont permis de prendre contact avec des choses instinctives, de manifestations directes qui allaient contre la fausse tradition dont j'avais horreur" (BRAQUE, In BRAQUE et alli, 1999, p. 21) . $^{4}$

Logicamente, este percurso de influências chegaria até a América Latina - e ao Brasil.

\section{Segunda parada: manifestações do negrismo na poesia caribenha}

A ideia de negrismo surge nas Américas, principalmente nas Antilhas, como consequência das vanguardas europeias e latino-americanas, associadas aos movimentos de abolição da escravatura, à emergência na cena pública do mosaico que representa a cultura popular e, consequentemente, nacional, e, como não poderia deixar de ser, à possibilidade de os povos poderem assumir a liberdade e a igualdade de modo a adquirir vozes próprias. No caso dos territórios americanos, este movimento implica imersão nos universos indígenas e afrodescendente, ficando, portanto, de fora o branco, justamente por ser considerado o opressor - inclusive no campo cultural.

Como rastro/resíduo da apropriação do universo negro realizado pelos artistas europeus, a cartografia do negrismo denota um tom poético, o qual se fez presente primeiramente na América Central, com Luiz Palés Matos e seu livro Tun tun de pasa y grifería (1924); em Cuba, com Ramón

determinante entre os jovens - adotaram temas negros com modificações criadoras”. (Tradução minha)

4 "As máscaras africanas também abriram-me um horizonte novo. Elas me permitiram tomar contato com coisas instintivas, manifestações diretas que iam contra a falsa tradição da qual eu tinha horror”. (Tradução minha) 
Guirao, Emilio Ballagas, Gomez Kemp, José Zacarías Tallet e Nicollás Guillén, sendo este o escritor de maior repercussão, autor de Motivos del son (1930), Sóngoro Cosongo (1931) e West Indies (1934); e, por fim, no Uruguai, com Ildefonso Peredas Valdés, tendo ele escrito, por exemplo, La guitarra de los negros (1926) e Raza negra (1929). No balanço de José Luis Varela, estes textos não passam de "emisiones de simpatia afrocubana, folklorismo epidérmico [...] erotismo religioso, misticismo yoruba", cuja força também reside na exploração do "sensualismo africano, aliteral, amelódico y onomatopéyco" (Varela, 1951, p. 93), a que os próprios negristas chamavam de fonetismo.

Nos anos seguintes, ocorre o que prefiro chamar de "consolidação do negrismo", haja vista a quantidade de publicações neste segmento: além dos já citados Sóngoro cosongo (1931) e West Indies (1934), de Nicolás Guillén, vem ao público La passion noir (1932) e Ecué yamba-O (1933), de Alejo Carpentier; Bongó (1934), de Ramón Guirao; Cuaderno de poesía negra (1934), de Emilio Ballagas; e La luna de los ñáñigos (1936), de Lino Novás Calvo. Todos estes exemplos foram construídos a partir do uso de uma linguagem e ritmo popularescos, explorando as figuras e os temas da cultura mestiça de origem africana (sobretudo iorubana) sem esquecer, é claro, da denúncia e da reivindicação social.

Exemplo negrista, o livro Motivos de son, de Nocolás Guillén, por exemplo, é composto de oito poemas, entre os quais está "Negro bembón”. A estrutura fonética serve como diapasão da voz da coletividade cubana, a qual o livro tenta "imitar". Em "Negro bembón”, o poeta apresenta várias características estilísticas, semânticas e fonéticas de sua produção poética, todas elas fabricadas a partir da herança africana: "Negro bembón/ ¿Po qué te pone tan brabo,/ cuando te disen negro bembón/ si tiene la boca santa,/ negro bembón?” (Guillén, Nicolás. In http://www.fguillen.cult.cu/guigale/071.htm, acesso em 19 de janeiro de 2011).

Sem dúvida, ao lado de Guillén, Palés Matos foi um dos principais autores caribenhos a trazer para a literatura uma expressividade musical colhida de África. As marcações rítmicas de seus textos sempre seguem os ritmos de agogôs. O compromisso atestado no ritmo é esvaziado de sentido político justamente porque o exotismo preside boa parte de seus poemas. Não se desconsidera, porém, que este artifício de implantar na língua de Castela elementos africanos seja uma tentativa de solapar o enrijecimento das possibilidades poéticas e, ao mesmo tempo, um apontamento para novos rumos para o Caribe, entendido aqui como uma confluência de culturas, de temporalidades, de histórias. 
Pasam tierras rojas, islas de betún:

Haití, Martinica, Congo, Camerún;

las papiamentosas antillas del ron

y las patualescas islas del volcán,

que el grave son

del canto se Dan (idem).

A aglutinação do castelhano com vocábulos afrodescendentes colhidos pelo artista aqui e ali, ou inventados, cria uma atmosfera desconexa, que dificulta a compreensão do texto em sua totalidade. Contudo, cada um destes vocábulos, dada a ressonância de sua peculiar estruturação fonética e sua evocação imaginativa, mantém um positivo valor estético.

O negrismo nas Antilhas não foi apenas um "movimento" literário, mas se fez presente em meios diversos, como a pintura, a escultura, o desenho, a gravura e a música. Conquistou, além disso, outros meios de difusão com destaque para o rádio, o cinema e, posteriormente, a televisão.

\section{Terceira parada: manifestações do negrismo na poesia brasileira}

O Modernismo brasileiro recebeu inspiração de diversos movimentos, como o Cubismo, o que abre espaço para a solidificação da presença do negro no campo das nossas letras. Cabe destacar que a visita de Blaise Cendrars ao Brasil, em 1924, que publicara a notável Anthologie nègre três anos antes deste acontecimento, assim como uma efervescência representativa do negro nas artes, não foram capazes nem de romper os lugares comuns dos estereótipos, nem ainda conseguiram impulsionar a primazia do negro em relação ao índio, vistos aqui enquanto agendas sociais.

O Modernismo brasileiro pouco alterou a imagem do negro no campo das letras. Conforme assevera radicalmente Roger Bastide (1973), a literatura brasileira do início do século XX apenas troca o racismo do século XIX por uma "simpatia diluída" que tendia a acumular o "pai João", com os estereótipos e epítetos da simplicidade, da bondade e da alegria natural (Bastide, 1973, p. 21). O negro - e a própria África - nos poemas brasileiros, incluindo aqui o Modernismo, pouco se aproximam do real, seja ele de ontem ou de hoje. Se os epítetos presidem a representação 
majoritária do negro, a África é eleita como símbolo vazio ou ausente, chegando por vezes a ser fantasiosa. Ou, como quer Pires Laranjeira, "a composição é esquemática, escassa”, sem elementos que permitam ao leitor construir uma imagem expressiva, complexa, realista, com base "em pormenores históricos, políticos, culturais ou geográficos" (Laranjeira, 1995, p. 202). Neste sentido, o negro e a África são apenas apelos, elementos pitorescos, imagens livrescas orientadas por paradigmas europeus e/ou caribenhos.

Diante desta questão, vale a pena destacar que muitos intelectuais e escritores brasileiros se voltavam para a tematização da raça e da classe como forma de abrir a discussão acerca dos limites da modernidade, da identidade nacional e do lugar das alteridades na economia social. Exemplificam tais situações Raul Bopp, com Urucungo (1932); Jorge de Lima, com Poemas (1927) e Poemas negros (1947); e Mário de Andrade, com Poemas da negra (1929).

De acordo com Jorge Schwartz (1995), estes autores estiveram preocupados com a exploração de elementos culturais africanos ou trazidos na diáspora e vistos como exóticos, a divulgação da culinária, da musicalidade e da dança de origem africana, ou seja, com um "folclorismo negro" que anima boa parte de suas produções artísticas em verso e atualiza o sentido nacionalista e coletivista dos primeiros anos do Modernismo brasileiro.

Cabia-lhes, portanto, "corrigir" as contradições sociais e emancipar os indivíduos marginalizados dos "anacronismos" em que viviam. No caso do Brasil, os descompassos e as contradições entre o projeto de modernização política e sua prática estão explícitos pelas representações literárias que, se não serviram a um processo de revisão política por parte do Estado, serviram à pedagogia das classes dominantes, por meio da qual os demais indivíduos aprenderiam a pensar sobre o significado da nação, agora levando em conta, além do branco e do índio, o negro, construído muito mais próximo da África do que enquanto componente do próprio nacional.

A propósito, uma das cenas de maior importância no livro está presente no poema “África”. Aqui, a narração poética recria o surgimento do continente africano:

\section{África}

A floresta inchou.

Uma árvore disse:

Eu quero ser elefante.

$\bar{E}$ saiu caminhando no meio do silêncio. 


\section{Aratabá-becúm \\ Aratabá-becúm}

Aquela noite foi muito comprida.

Por isso é que os homens saíram pretos.

Aratabá-becúm (Bopp, 1956, p. 90)

De modo a reproduzir a tomada da palavra pelo griot, poeta detentor do saber, a "noite muito comprida" basta para fundar a criação e a justificativa da cor da pele de muitos africanos. O enunciador coloca em mesmo nível a "noite" e a "cor da pele", atribuindo a esta caráter positivo. A expressão "aratabá-becúm", por sua vez, aponta para a recuperação do som do tambor, instrumento bastante utilizado em rituais religiosos em diversos espaços africanos. Bopp utiliza, pois, esta estratégia para promover a valorização do coletivo negro e romper com estereótipos típicos do século XIX.

\section{Ponto de chegada: manifestações do negrismo em romances brasileiros}

Diversos foram os escritores, sobretudo no Modernismo, que buscaram encenar uma nova cartografia artística do país, a partir da justaposição tensa entre o local e o ocidental. O local, traduzido, sobretudo pela exploração de base etnográfica e nacionalista do nosso território, através da literatura, assume o universal para melhor inscrever o projeto existencial e, não obstante, cultural de cidadãos e matrizes étnicas negras e indígenas numa produção cultural até então avessa à diferença. Arrisco afirmar que seria indispensável dissimular, ainda que de maneira sutil e relutante, os traços autoritários da cultura dada como referência, vale dizer, a europeia, e questionar, sem, contudo, rejeitar ou repudiar veementemente, a universalidade imposta pela intolerância ocidental (Santiago, 2011, p. 164).

Houve lugar na cultura brasileira a partir dos anos de 1920, mas com desdobramentos ainda visíveis nas décadas finais do século passado, um grupo de artistas que julgou necessário fazer uma imersão no país, através da junção conciliatória da herança positiva da cultura colonizadora com a investidura em temas e assuntos pouco visitados anteriormente, como o 
universo afrodescendente. Em busca de novos valores estéticos, os artistas brasileiros optaram pela exploração máxima da temática étnica, a qual também constitui a nação. A interação entre as várias etnias foi reconhecida como forma e força original de nossa formação via "mestiçagem espontânea". Com o decorrer das décadas, na avaliação de Silviano Santiago, "o espontâneo foi concretizado e se transformou no pré-fabricado consensual da nacionalidade a construir", mesmo se, no empilhamento do molde, "se neutralizassem as justas aspirações dos grupos étnicos em recuperação identitária" (Santiago, 2011, p. 166-167). Assumindo um lugar intersticial, o artista se manteve simpático à causa que defendia, mas não parte das alteridades que dizia estar representando em seus textos. Havia, portanto, uma enorme distância entre o discurso político e o discurso artístico.

O escritor negrista, ao mesmo tempo em que opera transformações no cenário social, insere em seu discurso e atitude política aspecto próprio de um coletivo oprimido, que ainda reproduz no âmbito de seu discurso literário propriamente dito, posicionamento tipicamente conservador. Até porque os escritores negristas não só advêm da camada dominante - e falam deste lugar - mas também é notório que reproduzem, em parte, o pensamento autoritário brasileiro, recaindo, pois, na mestiçagem de vetor único em direção ao branqueamento. O resultado desta equação é um discurso conciliatório, fruto da tentativa de justaposição entre um posicionamento progressista e conservador.

A proposta do negrismo no romance em questão é a apropriação da temática negra a partir da exploração do exotismo que o universo abordado carrega aos olhares dos autores, bem como a utilização bastante carregada da comicidade e do erotismo. Aliás, penso que é exatamente o humor associado ao erótico os dois procedimentos principais na condução dos enredos dos romances. Os enredos contêm temas caros ao universo afrodescendente. Porém, justamente pelas vias do cômico, do exotismo e do erotismo, as cenas pouco abordam o negro enquanto sujeito, em sua inteireza. Talvez seja demasiado dizer que o objetivo é a exploração do outro a fim de torná-lo "palatável" ao gosto branco ou que o desejo de romper com o passadismo e com a estética bem comportada acabou por favorecer justamente estas imagens. Fato é, contudo, que estes percursos ambíguos, de ruptura, por um lado, e folclorização, por outro, a meu ver, encontram-se nos alicerces dos romances negristas.

Já em Os tambores de São Luís (1975), de Josué Montello, o bom-humor e uma aparente subserviência, regada de sorrisos, fazem com que o personagem Barão, por exemplo, seja 
totalmente admirada por todos à sua volta. E este jeito bonachão norteia a trajetória da personagem num projeto de combate ao cativeiro e à discriminação. Não que ele seja contrário à liberdade. Ele é apenas contrário à carta de alforria numa sociedade que não pensou o destino que dará aos negros libertos. Barão não é contrário ao contato sexual entre brancos e negros. Por isso, paralelamente a esta estratégia apegada à malandragem, Barão empreende outra, deveras muito engraçada: a de "emprenhar os buchos das brancas", como ele mesmo diz e, a partir deste ponto, insere na narrativa a tese da miscigenação, cujo resultado é o apagamento do fenótipo negro. Certa vez, quando Damião fora ultrajado por Tertuliano, e relata o caso a Barão, este explica ao amigo a sua estratégia:

- Não te aborreças comigo - suplicou o Barão, ainda a rir. Não estou rindo de ti, estou rindo do bilheteiro. Conheço ele. É o Tertuliano. Um pobrediabo. Já passei o lápis na mulher dele. É um corno conhecido. Casou já velho com uma brancarana cheia de sardas, e tão frouxa que não pede bis. Ela gosta de preto; ele odeia. Principalmente depois que soube que eu andei com ela. Eu te vinguei adiantado, Damião (Montello, 1976, p. 365).

Barão fazia questão de engravidar as mulheres brancas com quem se relacionava. Este ato, espalhado aos quatro cantos da cidade, acabaria por ridicularizar os maridos. Segundo o “malandro", não deixar "pistas do ato" é o "segredo do negócio", a não ser que esta pista seja mesmo um mulatinho, isto é, prova de que as brancas apreciam de fato a sexualidade afrodescendente em detrimento do homem branco. Eis as palavras da personagem:

- Tu estás calado demais, Damião. Que é que há contigo? Ainda não esqueceste o que te fez o corno do Tertuliano. Deixa isso comigo. Por ti, sou capaz de outro sacrifício: torno a pôr mais chifres na cabeça dele. Essa briga de preto com branco, aqui no Brasil, vai acabar mais depressa do que se pensa. E acaba devagarinho - na rede, ou na cama, conforme o gosto, ou até mesmo no chão, em cima de uma esteira. Daqui a pouco, quando se quiser ver mesmo um preto, não tem mais para ver. Está tudo desbotado. Hoje mesmo, de tardinha, papei uma branca vistosa, e acho que daí vai sair mais um mulatinho. Tomara que sim. (Montello, 1976, p. 366) [marcas minhas]

Para Barão, a mestiçagem é a saída possível para a questão do preconceito de cor. Ele defende que o mulato é o brasileiro por excelência, e, por consequência, devem ser cultivadas as relações interétnicas. Barão não defende só o branqueamento da população, mas a mulatização do negro, tal como concluirá Damião ao conhecer seu trineto. Penso que a estratégia de Barão peca por 
amenizar o conflito étnico e porque repete a posturas de diversos pensadores da "raça brasileira"; por outro lado, ao menos altera o vetor da mestiçagem brasileira.

Se em Macunaíma e em Os tambores de São Luís temos a representação do negro de modo estilizado, calcada ainda nos parâmetros do clareamento étnico da população e na mestiçagem como solução pacífica para nossos conflitos, em A casa da água (1969), de Antônio Olinto, temos outra forma de negrismo. Neste caso, as personagens negras são valorizadas. Os acontecimentos históricos subjacentes às cenas literárias trazem o afrodescendente enquanto sujeito do processo. Embora haja um mosaico de personagens e funções exercidas pelas negras, o texto escolhe focalizar a vocação empreendedora de Mariana. A opção de destacar esta personagem ligada ao campo da intelectualidade e do sucesso financeiro por si só contrasta com a imagem corrente das personagens negras na literatura brasileira.

Schumpeter (1985) faz uso da categoria empreendedor, para criticar a teoria econômica clássica e mostrar que este modelo não é capaz de incorporar a análise da dinâmica e do desenvolvimento econômico. Segundo o economista, inovar produz tanto desequilíbrio quanto desenvolvimento num contexto em que a competição não se dá por meio do preço, mas sim da tecnologia. Trata-se de uma situação diferente daquela gerada pelo crescimento econômico enquanto aumento do capital. Este é importante, mas a ampliação de ferramentas para o desenvolvimento do processo produtivo abre campos para outras atividades econômicas. Estas considerações parecem explicar as ações da personagem Mariana:

A notícia de que o governo ia construir poços não era muito agradável, Mariana percorreu a beira-mar no dia seguinte, viu uma casa que fora bonita, tinha quatro portas de frente, daria uma boa loja, procurou saber quem era o dono, em casa conversou com Antônio:

- Vamos abrir uma loja de móveis na Marina. Você e o João das Tábuas fabricam os móveis, eu vendo. Além dos móveis, posso vender outras coisas também e importar mercadorias no Brasil.

Deteve-se um instante e acrescentou.

- Ou da Inglaterra (Olinto, 1975, p. 131).

A empreendedora Mariana não age por hábito, nem por qualquer tipo de impulso e/ou condicionamento à rotina ou repetição mecânica, menos ainda orientada por tradições religiosas, étnicas, familiares etc. O sentido de sua ação está centrado na inovação como um valor. 


\section{Desembarque}

O negrismo não é um movimento articulado através de manifestos ou qualquer meio de arregimentação. Trata-se de uma linhagem de romances (e outros objetos artísticos) que utilizam o tema negro enquanto procedimento constitutivo. Enquanto fenômeno, o negrismo de que tratamos encontra ambiente propício já em fins do século XIX, didaticamente falando, mas passa a ganhar força pelos primeiros anos do Modernismo, com Macunaíma, de Mário de Andrade; atravessa o século XX, até perder fôlego em meados dos anos de 1980, com Viva o povo brasileiro, de João Ubaldo Ribeiro. Mesmo assim, encontra forças para chegar à década de 1990, quando é publicado o livro O trono da rainha Jinga, de Alberto Mussa.

A linhagem em questão bebe nas fontes do Cubismo europeu, o qual utiliza o negro enquanto tema, a partir de uma enunciação externa e que o coloca como exótico. Pode-se dizer que os sujeitos textuais em ambos os casos atendem a um desejo de renovação temática tanto nas artes plásticas quanto nas Letras. O negrismo no universo do romance brasileiro ainda dialoga com o negrismo poético caribenho, assim como encontra pontos em comum com o negrismo poético brasileiro, com o qual se entrecruza em diversos aspectos. Pode-se dizer que o tema negro é um dentre os temas e não $o$ motivo mais importante das agendas literárias dos escritores. Arriscaria dizer que, em alguns casos, se tratou de um "modismo" ou um deslocamento por um circuito temático cuja urgência chamava a atenção não só para os problemas nacionais ainda sem solução, como os étnicos, mas também despertava a atenção de diversos leitores.

No que tange à tematização do negro, são reconhecidos os esforços dos trabalhos dos autores brancos, canônicos ou não, de nossa literatura. Muitas vezes, representaram consciência possível para determinada época. Até os anos 1970, muitos conseguiram cavar espaço para a inserção das alteridades na arte da palavra. Muitos podem questionar que se trata de uma visão externa, sem dúvidas, mas mesmo assim foi uma forma válida de levantar as demandas do outro/pelo outro. Localizo a década de 1970 do século passado, pois considero como divisor de águas a série Cadernos Negros, a qual, de fato, consolida uma permanência editorial de autores afrodescendentes, o que resulta na formação de um público leitor. A partir dos anos de 1980, paralelamente à ascendência da chamada literatura afro-brasileira, iniciada na década anterior, $\mathrm{o}$ 
negrismo enquanto procedimento começa a perder o sentido de sua existência. Logo, se estabelece o sistema, na concepção que Antonio Candido desenvolve em Formação da literatura brasileira momentos decisivos (1959). Não apago as iniciativas anteriores à série citada, mas o sistema não se fechava até então, por diversas razões, que não me são caras discutir aqui. Neste sentido a desassimilação, proposta pelos negristas, é positiva.

Na minha visão, o negrismo contribuiu significativamente para a incorporação da cultura afro-brasileira na literatura tout court do país, especialmente do Nordeste, Minas Gerais e em São Paulo, lugares onde a presença de escravos havia sido a maior e a mais longa - e esta parece ser a explicação mais plausível. Por essa razão, evidencia-se, a meu ver, uma ressignificação do nativismo, baseado no elemento africano, em alguns escritores negristas, os quais, sem dúvida, contribuíram para "desassimilar" o negro, porém não deixando de recair em exotismos e estereótipos. Trata-se de uma tomada de postura por parte do escritor, tanto para combater a "arte pela arte" e o tradicionalismo quanto para inserir-se como agente transformador social. Contudo, não posso me abster da crítica a estas posturas. E é neste ponto que questiono a efíciência da desassimilação "feita de fora", porque, na minha visão, reside aqui outro perigo: um interesse meramente paternalista pelas alteridades. Assim como David Brookshaw, penso que o condicionamento do escritor branco ao simbolismo tradicional da relação branco X preto pode trair seu preconceito interior, esteja ou não escrevendo em favor do negro, ou usando sua cultura em demonstração de seu próprio nativismo. E isto também indica sua incessante dependência dos valores culturais europeus.

O negrismo contemplou uma vasta gama de temas. Abordou a abolição, centrando-se em muitos momentos dela; discutiu a falta de projetos para a integração do negro na sociedade; trouxe a chave risível, a fim de inserir, por meio dela, a figura do afrodescendente; questionou a violência incidente contra os de pele escura; resgatou personagens históricos afro-brasileiros; recontou capítulos pouco conhecidos do nosso passado; discutiu imagens de negros recorrentes ao longo de nossa literatura; e, por fim, tratou da miscigenação e do branqueamento como saídas para os problemas étnicos do país.

A autoria dos textos é de sujeitos brancos ou mulatos. Não há a experiência do ser negro colocada de maneira subjetiva, ainda que na tentativa de simular um enunciador interno à negritude. Isso não é um problema, mas evidencia o ponto de vista externo que preside os textos. 
Falando em ponto de vista, os narradores se colocam em terceira pessoa. A "fala pelo outro", que se processa nos romances analisados em nosso trabalho, define o negrismo e o afasta da literatura afro-brasileira propriamente dita. Isso porque os enunciadores se colocam o tempo todo como brancos, ainda que simpáticos aos problemas que envolvem os negros. Em diversos momentos, estes são elementos axiais para a discussão de outros temas, como a formação nacional.

A linguagem, matéria-prima dos romances, aponta para o aproveitamento de ritmos, de palavras e de construções sintáticas já utilizadas em outros momentos, como no negrismo caribenho. Ela se comporta como tentativa de veiculação de todo um conjunto de valores africanos e afro-brasileiros que são disseminados nos textos que analisamos.

Como tenho pontuado aqui e ali neste trabalho, salta aos olhos o lugar de enunciação de textos produzidos pelos autores brancos sobre a cultura negra. Claro que este ato não deixa de trazer avanços. É óbvio que a questão de assimilação e desassimilação envolve mudanças sutis no papel e nas diversas roupagens das imagens de negros. Via de regra, um texto estritamente etnocêntrico, por exemplo, enfatiza os estereótipos negativos do negro, representando-o como selvagem, como violento ou como elemento subjugado na sociedade, de modo a tratar a presença cultural do afrobrasileiro como retrógrada e primitiva, sem promover qualquer relativização (e, sobre isso, já se posicionaram diversos estudiosos). Penso que esta atitude é reflexo de quem aspira que o Brasil seja um país de brancos. O texto negrista, por outro lado, é mais propenso a retratar o negro e sua cultura como possuidores de qualidades instintivas e de uma espiritualidade saudável. Por consequência, o Brasil, transmutado em literatura negrista, é o instrumento com o qual o escritor, se não rejeita, ao menos questiona a cultura e os valores sociais a partir de sua própria classe. Com isso, corre-se o risco de o afro-brasileiro tornar-se essencialmente uma figura mítica e plástica, um produto do populismo e exotismo estético de seu criador.

Especialmente no romance, o branqueamento é a tentativa artificial de conciliação entre os agentes do flagrante conflito étnico-social que o país vive desde a Abolição. E a conciliação é estratégia literária para o projeto negrista: a ficção como operadora de mediação. Contudo, não se pode deixar de reconhecer, há uma relativa defesa dos desfavorecidos, justamente porque a voz senhorial promove antes a cordialidade entre as partes em vez da construção da cidadania plena.

Um dos aspectos mais recorrentes em nossa sociedade é a celebração do contato entre as matrizes culturais que nos formaram. Muitas vezes, este contato é lido de forma bastante suave, 
como se de fato vivêssemos em uma sociedade harmônica e equitativa, sob todos os aspectos. Como se não houvéssemos passado pela colonização portuguesa, pela escravidão, por diversos conflitos internos e por tentativas inúmeras de diluição de nossas identidades.

Penso que o negrismo cumpre uma etapa de transição entre a literatura etnocêntrica e a literatura afro-brasileira propriamente dita. Diria ainda que aquela ajudou na formulação da consciência crítica e maturação desta. Penso também que este movimento ainda favorece a apropriação do negro enquanto horizonte estético e palatável ao grande público, desde que estilizado e temperado ao gosto dominante, através do exotismo, do erotismo, da cordialidade e da miscigenação.

Quero com isso, dizer que o negrismo suaviza a força do discurso da literatura afrobrasileira, justamente porque nega o que ela tem de mais forte: a crítica veemente ao preconceito e a potência do debate acerca dos problemas étnicos a partir do ponto de vista interno.

\section{Referências bibliográficas}

BARRETO, Lima. Diário íntimo: memórias. São Paulo: Globus Editora, 1956.

BASTIDE, Roger. Estudos afro-brasileiros. São Paulo: Perspectiva, 1973.

BOPP, Raul. Cobra Norato e outros poemas. 6 ed. Rio de Janeiro: Livraria São José, 1956.

BRAQUE, MATISSE, PICASSO, DERAIN, VLAMINCK, COCTEAU, GRIS, BRANUSI.

Opinions sur l'art nègre. Toulouse: Toguna, 1999.

BROOKSHAW, David. Raça e cor na literatura brasileira. Porto Alegre: Marcado Aberto, 1983.

CANDIDO, Antonio. Formação da literatura brasileira: momentos decisivos. São Paulo: Martins, 1959.

COSTA E SILVA, Alberto da. "Uma visão brasileira da escultura tradicional africana" In COSTA E SILVA, Alberto da. O quadrado amarelo. São Paulo: Imprensa Oficial do Estado de São Paulo, 2009. p. 12-45.

DUARTE, Eduardo de Assis; FONSECA, Maria Nazareth Soares (Orgs.).Literatura $e$ afrodescendência no Brasil: antologia crítica. v. 4. Belo Horizonte: Editora da UFMG, 2011. p. 375-403.

.Machado de Assis afro-descendente: escritos de caramujo. Rio de Janeiro: Pallas; Belo Horizonte: Crisálida, 2007.

GOLDING, John. Cubism: a history and an analysis, 1907-1944. London: Publication Year, 1959.

GUILLAUME, Paul. La sculpture nègre et l'art moderne. Toulouse: Toguna, 2006. 
LARANJEIRA, José Luiz Pires. A negritude africana de língua portuguesa. Porto: Edições Afrontamento, 1995.

MONTELLO, Josué. Os tambores de São Luís. 2 ed. Rio de Janeiro: José Olympio, 1976.

SANTIAGO, Silviano. "Destino: Globalização. Atalho: nacionalismo. Recurso: cordialidade". In DUARTE, Eduardo de Assis; FONSECA, Maria Nazareth Soares. Literatura e afrodescendência no Brasil: antologia crítica. V. 4. Belo Horizonte: Editora UFMG, 2011. p. 162-181.

SCHWARTZ, Jorge. "Negrismo e negritude". In SCHWARTZ, Jorge (Org.). Vanguardas latinoamericanas. São Paulo: EDUSP, 1995. p. 579-590.

SCHUMPETER, Joseph. A teoria do desenvolvimento econômico. Rio de Janeiro: Nova Cultural, 1985.

SOUZA, Florentina da Silva. Afrodescendências em Cadernos Negros e Jornal do MNU. Belo Horizonte: Autêntica, 2005.

VARELA, José Luis. Ensayos de poesia indígena en Cuba. Madrid: Ed. Cultura Hispanica, 1951. www.moma.org, acesso em 17 de abril de 2011.

www.masque-africain.com/masques-africains.html, acesso em 13 de março de 2012. 